\title{
Activation of an Imprinted Allele of the Insulin-like Growth Factor II Gene Implicated in Rhabdomyosarcoma
}

\author{
Shili Zhan, David N. Shapiro, ${ }^{\star}$ and Lee J. Helman \\ Molecular Oncology Section, Pediatric Branch, National Cancer Institute, Bethesda, Maryland 20892; and *Department of Experimental \\ Oncology, St. Jude Children's Research Hospital, Memphis, Tennessee 38101
}

\begin{abstract}
The insulin-like growth factor II (IGF2) gene is exclusively silent at the maternal allele in the mouse as well as in normal human tissues and is expressed at a high level in rhabdomyosarcoma (RMS). We report here that the normally imprinted allele of the IGF2 gene is activated in RMS tumors as well as in one RMS cell line. Since overexpression of IGF2 has been shown to be important in the pathogenesis of RMS, our data suggest that loss of imprinting (LOI) may lead to overexpression of IGF2 and play an important role in the onset of RMS. Furthermore, embryonal RMS usually has loss of heterozygosity ( $\mathrm{LOH}$ ) with paternal disomy of the IGF2 locus. One informative embryonal RMS tumor evaluated in this study was heterozygous at the IGF2 allele and had LOI, raising the possibility that LOI may be the functional equivalent of $\mathrm{LOH}$ in this tumor with both events leading to overexpression of IGF2. (J. Clin. Invest. 1994. 94:445-448.) Key words: IGF2 • rhabdomyosarcoma • alleles • human • neoplasm
\end{abstract}

\section{Introduction}

Rhabdomyosarcoma is the most common soft-tissue sarcoma of childhood and has been associated with overexpression of IGF2 (1). Furthermore, rhabdomyosarcoma (RMS) ${ }^{1}$ is an embryonal tumor that occurs in patients with Beckwith-Wiedemann syndrome (BWS), a fetal overgrowth syndrome associated with paternal disomy of $11 \mathrm{p} 15$, where the human IGF2 gene has been mapped $(2,3)$. Genomic imprinting, a gametespecific modification causing differential expression of the two somatic alleles of a gene, has been considered to play a role in human disease and cancer $(4 ; 5)$. Since IGF2 is maternally imprinted in the mouse (6), it has been suggested that loss of

Address correspondence to L. J. Helman, M.D., Pediatric Branch, National Cancer Institute, 9000 Rockville Pike, Bldg. 10/13N240, Bethesda, MD 20892.

Received for publication 12 October 1993 and in revised form 28 February 1994.

1. Abbreviations used in this paper: BWS, Beckwith-Wiedemann syndrome; LOH, loss of heterozygosity; LOI, loss of imprinting; RMS, rhabdomyosarcoma; RT, reverse transcriptase; UPD, uniparental disomy.

The Journal of Clinical Investigation, Inc.

Volume 94, July 1994, 445-448 heterozygosity ( $\mathrm{LOH}$ ) with paternal disomy at $11 \mathrm{p} 15$ may lead to increased expression of IGF2 from two active paternal alleles (7). It was recently reported that human IGF2 is also maternally imprinted but is biallelically expressed in some Wilms' tumors, another tumor associated with BWS $(8,9)$. For these reasons, we examined normal fetal tissue and RMS for imprinting at the IGF2 locus.

\section{Methods}

Tissue samples. All patient tumor samples were obtained from a tumor tissue bank of samples from patients with RMS treated at St. Jude Children's Research Hospital (Memphis, TN) or Texas Children's Hospital (Houston, TX), and all samples had been confirmed to contain viable tumor. Tumors were classified as being either of embryonal or alveolar histology according to the original classification of Horn and Enterline (10). 90-100-d fetal tissue specimens were obtained from the Central Laboratory of Human Embryology (Dr. Thomas H. Shepard, University of Washington, Seattle, WA).

PCR amplification of DNA and RNA. PCR amplification of $1 \mu \mathrm{g}$ of DNA was done using an initial denaturation for $4 \mathrm{~min}$ at $94^{\circ} \mathrm{C}$, then 35 cycles at $94^{\circ} \mathrm{C}$ for $1 \mathrm{~min}, 55^{\circ} \mathrm{C}$ for $1 \mathrm{~min}, 72^{\circ} \mathrm{C}$ for $2 \mathrm{~min}$ followed by a final extension at $72^{\circ} \mathrm{C}$ for $7 \mathrm{~min}$. Primers used were P1 $\left(5^{\prime}-\right.$ CTTGGACTTTGAGTCAAATTGG-3'), P2 (5'-GGTCGTGCCAATTACATTTCA-3' $3^{\prime}(8,11)$. PCR products were chloroform extracted, ethanol precipitated, digested with ApaI, and electrophoresed on a $2 \%$ agarose gel. The ApaI-undigested and digested alleles were named allele $a$ and allele $b$, respectively. RNA was transcribed into cDNA using reverse transcriptase (RT) and $0.5 \mu \mathrm{g}$ total RNA at $42^{\circ} \mathrm{C}$ for $1 \mathrm{~h}$. Subsequent amplification was carried out as above (RT-PCR). To eliminate DNA contamination, total RNA was treated by DNasel at $37^{\circ} \mathrm{C}$ for $2 \mathrm{~h}$ before RT-PCR and RT-PCR was performed in the presence (+RT) and absence $(-\mathrm{RT})$ of reverse transcriptase.

Determination of the $t(2 ; 13)(q 35 ; q 14)$ translocation. The presence of the $\operatorname{der}(13)$ fusion transcript produced by the tumor specific $\mathrm{t}(2 ; 13)(\mathrm{q} 35 ; \mathrm{q} 14)$ was determined by RT-PCR. This fusion product results from the translocation of 5' PAX3 sequences from chromosome 2 into the DNA binding domain of a forkhead transcription factor on chromosome 13 (12-14). The two primers used were PAX1203 (5'-AGACAGCTTTGTGCCTCCGTC-3') and FKH1507 (5'-CATCATTGCTGTGAGCCAG-3'), producing a 304 bp fragment spanning the der(13) breakpoint. RNA was transcribed into cDNA using reverse transcriptase, and subsequent amplification was carried out using an initial denaturation of $4 \mathrm{~min}$ at $94^{\circ} \mathrm{C}$, then 39 cycles at $94^{\circ} \mathrm{C}$ for $1 \mathrm{~min}, 60^{\circ} \mathrm{C}$ for $2 \mathrm{~min}, 72^{\circ} \mathrm{C}$ for $3 \mathrm{~min}$ followed by a final extension at $72^{\circ} \mathrm{C}$ for $10 \mathrm{~min}$.

\section{Results}

Monoallelic expression of IGF2 in normal fetal tissue. To determine the IGF2 allelic expression in fetal tissue and RMS, we used an ApaI restriction enzyme fragment length polymorphism 
A
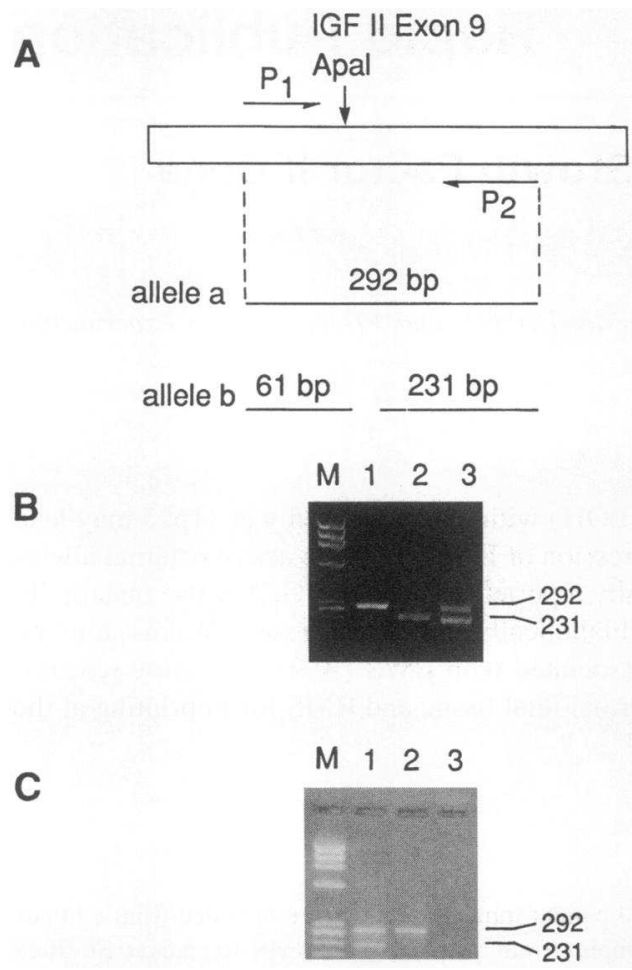

Figure 1. (A) Map of the $3^{\prime}$ end the IGF2 gene and size of PCR products digested by ApaI. (B) Three typical allele genotypes. M, ø174 RF DNA/HaeIII fragments (molecular weight sizes in bp 1353, $1078,872,603,310,281 / 271,234,194,118,72$ ), 1,aa, 2,bb, and 3,ab. PCR products were digested with ApaI. $(C)$ Monoallelic expression of IGF2 in fetal muscle. M, $₫$ X174RF/HaeIII fragments, I, DNA-PCR, 2, RT-PCR (+RT), 3, negative control RT-PCR (-RT). PCR products were digested with ApaI.

(RFLP) in exon 9 of the IGF2 gene (Fig. $1 A$ ). DNA and RNA from three normal fetal tissues were amplified by PCR and the products were digested with ApaI. Three representative allelotypes are shown in Fig. $1 \mathrm{~B}$. Our data confirms previous reports $(8,9)$ that in normal tissue, IGF2 is expressed monoallelically. Of six informative fetal tissues examined, all transcribed IGF2 monoallelically (Fig. $1 C$ and Table I).

Biallelic expression of IGF 2 in RMS. Of 35 RMS tumors and 9 RMS cell lines examined, 6 tumors and 1 cell line were

Table I. IGF2 Allele Expression in Fetal Tissue of Six Informative Tissues

\begin{tabular}{llc}
\hline & \multicolumn{2}{c}{ Allelotypes } \\
\cline { 2 - 3 } \multicolumn{1}{c}{ Fetal tissue } & (DNA) & (cDNA) \\
\hline Muscle fetus 1 & $\mathrm{a} / \mathrm{b}$ & $\mathrm{a}$ \\
Liver & $\mathrm{a} / \mathrm{b}$ & $\mathrm{a}$ \\
Kidney & $\mathrm{a} / \mathrm{b}$ & $\mathrm{a}$ \\
Brain & $\mathrm{a} / \mathrm{b}$ & $\mathrm{a}$ \\
Muscle fetus 2 & $\mathrm{a} / \mathrm{b}$ & $\mathrm{b}$ \\
Muscle fetus 3 & $\mathrm{a} / \mathrm{b}$ & $\mathrm{a}$ \\
\hline
\end{tabular}

All samples had monoallelic expression of IGF2. IGF2 alleles are designated $a$ and $b$, as defined in Methods.
Table II. IGF2 Allelic Expression in RMS Tumors and Cell Lines

\begin{tabular}{|c|c|c|c|c|}
\hline \multirow[b]{2}{*}{ RMS tumors } & \multicolumn{2}{|c|}{ Allelotypes } & \multirow[b]{2}{*}{ Histology } & \multirow[b]{2}{*}{$\mathrm{t}(2,13) \mathrm{PCR}$} \\
\hline & (DNA) & (cDNA) & & \\
\hline 1. & $a / b$ & $a / b$ & A & + \\
\hline 2. & $a / b$ & $a / b$ & A & ND \\
\hline 3. & $\mathrm{~b} / \mathrm{b}$ & & $\mathbf{A}$ & + \\
\hline 4. & $a / b$ & a & $\mathbf{A}$ & + \\
\hline 5. & $\mathrm{~b} / \mathrm{b}$ & & A & + \\
\hline 6. & $\mathrm{~b} / \mathrm{b}$ & & A & + \\
\hline 7. & $\mathrm{~b} / \mathrm{b}$ & & A & ND \\
\hline 8. & $a / b$ & $a / b$ & A & ND \\
\hline 9. & $b / b$ & & A & ND \\
\hline 10. & $b / b$ & & $\mathbf{A}$ & ND \\
\hline 11. & $\mathrm{a} / \mathrm{a}$ & & A & ND \\
\hline 12. & $b / b$ & & $\mathrm{E}$ & ND \\
\hline 13. & $b / b$ & & $\mathbf{E}$ & - \\
\hline 14. & $b / b$ & & $\mathrm{E}$ & ND \\
\hline 15. & $a / b$ & $a / b$ & $\mathrm{E}$ & - \\
\hline 16. & $\mathrm{~b} / \mathrm{b}$ & & $\mathrm{E}$ & ND \\
\hline 17. & $\mathrm{~b} / \mathrm{b}$ & & $\mathrm{E}$ & - \\
\hline 18. & $\mathrm{~b} / \mathrm{b}$ & & $\mathrm{E}$ & - \\
\hline 19 & $b / b$ & & $\mathrm{E}$ & - \\
\hline 20. & $\mathrm{a} / \mathrm{a}$ & & $\mathrm{E}$ & - \\
\hline 21. & $b / b$ & & $\mathbf{E}$ & ND \\
\hline 22. & $b / b$ & & $\mathrm{E}$ & ND \\
\hline 23. & $b / b$ & & $\mathbf{E}$ & ND \\
\hline 24. & $\mathrm{a} / \mathrm{a}$ & & $\mathbf{E}$ & ND \\
\hline 25. & $\mathrm{~b} / \mathrm{b}$ & & $\mathrm{E}$ & ND \\
\hline 26. & $b / b$ & & $\mathbf{E}$ & ND \\
\hline 27. & $\mathrm{~b} / \mathrm{b}$ & & $\mathbf{E}$ & ND \\
\hline 28. & $\mathrm{~b} / \mathrm{b}$ & & E & ND \\
\hline 29. & $b / b$ & & $\mathbf{E}$ & ND \\
\hline 30. & $b / b$ & & $\mathrm{E}$ & ND \\
\hline 31. & $b / b$ & & $\mathrm{E}$ & ND \\
\hline 32. & $b / b$ & & $\mathrm{E}$ & ND \\
\hline 33. & $\mathrm{a} / \mathrm{a}$ & & $\mathrm{E}$ & ND \\
\hline 34. & $a / b$ & $a / b$ & $\mathbf{U}$ & ND \\
\hline 35. & $\mathrm{~b} / \mathrm{b}$ & & $\mathbf{U}$ & ND \\
\hline RH18 & $\mathrm{b} / \mathrm{b}$ & & A & + \\
\hline RH28 & $a / b$ & $a / b$ & A & + \\
\hline RH30 & $\mathrm{a} / \mathrm{a}$ & & A & + \\
\hline RH3 & $\mathrm{b} / \mathrm{b}$ & & A & + \\
\hline RH4 & $\mathrm{b} / \mathrm{b}$ & & A & + \\
\hline $\mathrm{RD}$ & $\mathrm{a} / \mathrm{a}$ & & E & ND \\
\hline CTR & $\mathrm{b} / \mathrm{b}$ & & $\mathrm{E}$ & ND \\
\hline RH2 & $\mathrm{b} / \mathrm{b}$ & & $\mathrm{E}$ & - \\
\hline SA1 & $\mathrm{b} / \mathrm{b}$ & & $\mathrm{U}$ & - \\
\hline
\end{tabular}

Seven of 35 patients and one of nine RMS cell lines used in this study were heterozygous for the IGF2 Apa I RFLP. IGF2 alleles are designated $a$ and $b$, as defined in Methods. $A$, alveolar; $E$, embryonal; $N D$, not done; $U$, undifferentiated.

heterozygous at the IGF2 ApaI RFLP site. Of 7 informative cases, $5 / 6$ tumors and $1 / 1$ cell line lost IGF2 imprinting (Table II and Fig. $2 B$ ). These experiments demonstrate that the normally silent allele of the IGF2 gene can be activated in RMS. Furthermore, of all known embryonal tumors evaluated, only one was heterozygous for the IGF2 allele. Since this tumor has pre- 


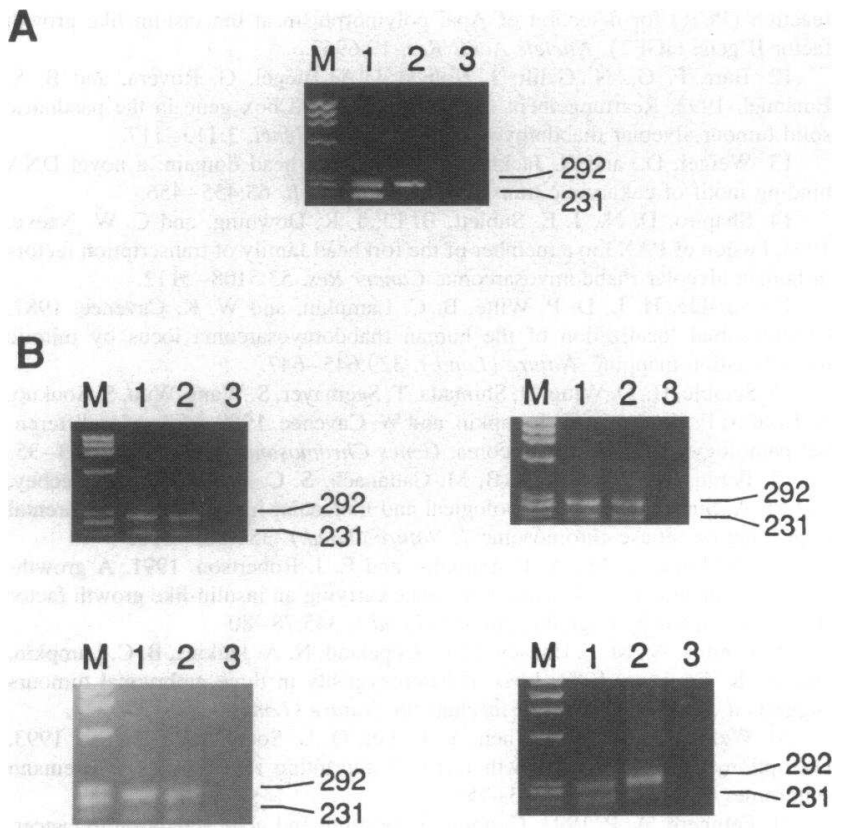

Figure 2. Analysis of IGF2 allelic expression in RMS. ( $A$ ) Heterozygous tumors with monoallelic IGF2 transcription. $(B)$ Heterozygous tumors or RMS cell line with biallelic IGF2 transcription. PCR products were digested with ApaI. M, $ø$ X174 RF DNA/HaeIII, (molecular weight sizes as in Fig. 1) 1, DNA-PCR; 2, RT-PCR (+RT); 3, negative control RT-PCR (-RT). Upper left, tumor 15; upper right, tumor 2; lower left, tumor 1; and lower right, $\mathrm{Rh} 28$.

viously been shown to have maternal allelic $\mathrm{LOH}$ at $11 \mathrm{p} 15$, including the IGF2 locus $(3,15,16)$, one would not anticipate loss of imprinting (LOI) in embryonal RMS since only the paternal allele remains and informative heterozygotes should not be seen. However, tumor 15 had embryonal histology and no evidence of the $\mathrm{t}(2 ; 13)$ translocation seen in alveolar histologies, but is polymorphic at the IGF2 locus and exhibits LOI at the RNA level (Table I). This paradox suggests that LOI of the IGF2 locus may function exactly the same as LOH with uniparental disomy (UPD) and can occasionally be found in embryonal RMS without LOH. Alveolar RMS is the other major histologic subtype of RMS and is characterized not by LOH at $11 \mathrm{p} 15.5$ but rather by a tumor specific $\mathrm{t}(2 ; 13)(\mathrm{q} 35 ; \mathrm{q} 14)$ translocation that has recently been molecularly identified (12). All the remaining tumors that were informative heterozygotes were alveolar or undifferentiated RMS.

\section{Discussion}

Our results indicate that activation of an IGF2 allele in alveolar RMS occurs at least in part through LOI of the IGF2 locus. Since LOH with paternal disomy of $11 \mathrm{p} 15.5$ has been demonstrated in embryonal RMS $(3,15)$, it appears that both alveolar and embryonal histologies of RMS have alterations of the normal IGF2 locus. Of particular note, the one embryonal tumor examined in this study that retained heterozygosity at the IGF2 locus, but demonstrated LOI, raises the possibility that loss of imprinting represents the functional equivalent of loss of heterozygosity with paternal disomy in RMS and that both events are related to the increased expres- sion of IGF2 seen in both histologic subtypes of RMS. The potential role of an increase in IGF2 gene dosage was suggested by the observation that the incorporation of a paternal duplication of mouse chromosome 7 (equivalent to human chromosome 11) into chimeras resulted in a striking growth enhancement of the embryos (17) while transgenic mice lacking a functional paternal IGF2 gene underwent growth retardation (18). Since overexpression of IGF2 has been considered to be important in the pathogenesis of RMS (1), loss of imprinting or paternal disomy of the IGF2 locus could contribute to the development of RMS and may play an important role in the pathogenesis of RMS.

The Beckwith-Wiedemann syndrome (BWS), which has concurrent high risk for the development of the embryonal tumors RMS, Wilms' tumor, and hepatoblastoma also has been associated with paternal disomy for the $11 \mathrm{p} 15.5$ region $(2,19)$ and it has been suggested that the resulting overexpression of IGF2 may be involved in the pathogenesis of this syndrome (7). Since activation of a normally imprinted maternal IGF2 allele could be the functional equivalent of paternal disomy of IGF2, and the normally imprinted IGF2 allele has now been shown to be activated in some RMS and Wilms' tumors, it could be predicted that early or global LOI might also occur in some BWS patients. This has indeed now been demonstrated in a recent report demonstrating LOI in fibroblasts and tongue tissue in some patients with the disorder (20).

Our data provide support for the potential role of loss of imprinting or uniparental disomy in gene activation in cancer as has recently been proposed (21). Simply stated, either LOI or LOH with UPD may lead to activation of biallelic expression from a locus that is normally transcriptionally active from only a single allele. The support mounting for this hypothesis has broad implications for general mechanisms of carcinogenesis. There are now many tumors and syndromes in which LOH has been implicated and presumed to point to as yet unidentified tumor suppressor genes. However, our results and the data reported recently in Wilm's tumor $(8,9)$ suggest that activation of a growth promoting gene, resulting from either UPD or LOI may play a role in other tumors where $\mathrm{LOH}$ has been reported. It is unlikely that IGF2 is unique in its apparent regulation by imprinting and therefore other growth promoting genes may be activated in specific tumors by UPD or LOI.

Genomic imprinting is believed to be caused by a modification which can normally be erased or reestablished when germ cells are produced in the next generation (4). The mechanism whereby maternal and paternal chromosomes in mammals can function differently is not well understood. Several studies indicate that DNA methylation may be involved (22, 23 ), but such correlative observations are not universal (2426 ). Only when the gene is transmitted from one generation to the next can the allelic expression of a normal imprinted gene be reversed, depending on the parental origin, which limits basic research into the mechanism of genomic imprinting. Until now, mammalian studies of imprinting have required the technically demanding generation of parthenogenetic embryos or transgenic mice. The mechanism of normal genomic imprinting may be investigated by studying abnormal loss of imprinting in tumors. Our finding, loss of imprinting in the cell line RH28, may provide a useful tool for such a study directly in human cells. Identification of the mechanisms of imprinting and LOI could lead to important insights into the mechanisms of tumorigenesis. 


\section{Acknowledgments}

We thank I. Kirsch and M. Israel for their helpful discussions, $M$. Finegold for providing tumor samples, and J. Hughes for the preparation of this manuscript.

D. N. Shapiro was supported in part by the National Institutes of Health grant CA-23099, Cancer Center Core grant CA-21765, and the American-Lebanese-Syrian Associated Charities (ALSAC).

\section{References}

1. El-Badry, O. M., C. Minniti, E. C. Kohn, P. J. Houghton, W. H. Daughaday, and L. J. Helman. 1990. Insulin-like growth factor II acts as an autocrine growth and motility factor in human rhabdomyosarcoma tumors. Cell Growth \& Differ. $1: 325-331$

2. Henry, I., C. Bonaiti-Pellie, V. Chehensse, C. Beldjord, C. Schwartz, G. Utermann, and C. Junien. 1991. Uniparental paternal disomy in a genetic cancerpredisposing syndrome. Nature (Lond.). 351:665-670.

3. Scrable, H., W. Cavenee, F. Ghavimi, M. Lovell, K. Morgan, and C. Sapiensa. 1989. A model for embryonal rhabdomyosarcoma tumorigenesis that involves genome imprinting. Proc. Natl. Acad. Sci. USA. 86:7480-7484.

4. Hall, J. G. 1990. Genomic imprinting: review and relevance to human diseases. Am. J. Hum. Genet. 46:857-873.

5. Reik, W., and M. A. Surani. 1989. Genomic imprinting and embryonal tumours. Nature (Lond.). 328:112-113.

6. DeChiara, T. M., E. J. Robertson, and A. Efstratiadis. 1991. Parental imprinting of the mouse insulin-like growth factor II gene. Cell. 64:849-859.

7. Little, M., V. Van Heyningen, and N. Hastie. 1991. Dads and disomy and disease. Nature (Lond.). 351:609-610.

8. Ogawa, O., M. R. Eccles, J. Szeto, L. A. McNoe, K. Yun, M. A. Maw, P. J. Smith, and A. E. Reeve. 1993. Relaxation of insulin-like growth factor II gene imprinting implicated in Wilms' tumour. Nature (Lond.). 362:749-751.

9. Rainier, S., L. A. Johnson, C. J. Dobry, A. J. Ping, P. E. Grundy, and A. P. Feinberg. 1993. Relaxation of imprinted genes in human cancer. Nature (Lond.). 362:747-749.

10. Horn, R. C., and H. T. Enterline. 1958. Rhabdomyosarcoma: a clinicopathological study and classification of 39 cases. Cancer. 11:181-199.

11. Tadokoro, K., H. Fujii, T. Inoue, and M. Yamada. 1991. Polymerase chain reaction (PCR) for detection of Apal polymorphism at the insulin like growth factor II gene (IGF2). Nucleic Acids Res. 19:6967.

12. Barr, F. G., N. Galili, J. Holick, J. A. Biegel, G. Rovera, and B. S. Emanuel. 1993. Rearrangement of the PAX3 paired box gene in the paediatric solid tumour alveolar rhabdomyosarcoma. Nature Genet. 3:113-117.

13. Weigel, D., and H. Jackle. 1990. The fork head domain: a novel DNA binding motif of eukaryotic transcription factor? Cell. 63:455-456.

14. Shapiro, D. N., J. E. Sublett, B. Li, J. R. Downing, and C. W. Naeve. 1993. Fusion of PAX3 to a member of the forkhead family of transcription factors in human alveolar rhabdomyosarcoma. Cancer Res. 53:5108-5112.

15. Scrable, H. J., D. P. Witte, B. C. Lampkin, and W. K. Cavenee. 1987. Chromosomal localization of the human rhabdomyosarcoma locus by mitotic recombination mapping. Nature (Lond.). 329:645-647.

16. Scrable, H. D. Witte, H. Shimada, T. Seemayer, S. Wang-Wuu, S. Soukup, A. Koufos, P. Houghton, B. Lampkin, and W. Cavenee. 1989. Molecular differential pathology of rhabdomyosarcoma. Genes Chromosomes \& Cancer. 1:23-35.

17. Ferguson-Smith, A. C., B. M. Cattanach, S. C. Barton, C. V. Beechey, and M. A. Surani. 1991. Embryological and molecular investigations of parental imprinting on mouse chromosome 7. Nature (Lond.). 351:667-670.

18. DeChiara, T. M., A. Efstratiadis, and E. J. Robertson. 1991. A growthdeficiency phenotype in heterozygous mice carrying an insulin-like growth factor II gene disrupted by targeting. Nature (Lond.). 345:78-80.

19. Koufos, A., M. F. Hansen, N. G. Copeland, N. A. Jenkins, B. C. Lampkin and W. K. Cavenee. 1993. Loss of heterozygosity in three embryonal tumours suggests a common pathologic mechanism. Nature (Lond.). 316:330-334.

20. Weksberg, R., D. R. Shen, Y. L. Fei, Q. L. Song, and J. Squire. 1993 Disruption of insulin-like growth factor 2 imprinting in Beckwith-Wiedemann syndrome. Nature Genet. 5:143-150.

21. Feinberg, A. P. 1993. Genomic imprinting and gene activation in cancer Nature Genet. 4:110-113.

22. Swain, J. L., T. A. Stewart, and P. Leder. 1987. Parental legacy determines methylation and expression of an autosomal transgene: a molecular mechanism for parental imprinting. Cell. 50:719-727.

23. Hadchouel, M., H. Farza, D. Simon, P. Tiollas, and C. Pourcel. 1987. Maternal inhibition of hepatitis B surface antigen gene expression in transgenic mice correlates with de nevo methylation. Nature (Lond.). 329:454-456.

24. Reik, W., A. Collick, M. L. Norris, S. C. Barton, and M. A. H. Surani. 1987. Genomic imprinting determines methylation of parental alleles in tumorigenic mice. Nature (Lond.). 328:248-251.

25. Sapienza, C., A. C. Peterson, J. Rossant, and R. Balling. 1987. Degree of methylation of transgenes is dependent on gamete of origin. Nature (Lond.). 328:251-254.

26. Williams, J. C., K. W. Brown, M. G. Mott, and N. J. Maitland. 1989. Maternal allele loss in Wilms' tumour [letter]. Lancet. 1:283-284. 